\title{
Tarascan dialectal and generational differences around aspirated stops
}

\author{
Francisco Javier Bucio García \\ Department of linguistics, El Colegio de México-UAM, Mexico \\ https://doi.org/10.36505/ExLing-2010/03/0017/000137
}

\begin{abstract}
The Tarascan or phurépecha language contrasts aspirated stops from non-aspirated word initially, but this contrast was hardly heard in Hiwatzio, a lake dialect (Friedrich 1971:177). We measured the length of the aspirated feature following stops and vowels /i a u/'s formants F1 and F2 so as to identify differences among subjects. The results show that adult men speakers from a mountain dialect make an aspiration shorter than men from a lake dialect. The opposite pattern applies for women belong to the same dialects. Regarding generational differences, a young man from a lake dialect does a shorter aspiration than the older men do and a young girl's F1 and F2 of /i, a, u/ tend to be higher than older women.
\end{abstract}

Key words: tarascan, aspirated, generational, dialectal differences.

\section{Previous analysis}

The Tarascan language is spoken in Michoacán Mexico and is divided into the lake and the mountain dialects. The first dialectal work reported that the contrast between aspirated and non-aspirated stops was hardly perceived for Hiwatzio speakers, a lake dialect (Friedrich 1971:177). A second dialectal work (Chavez 2004) points some phonological differences but does not report any lost in the stop contrast. A subsequent dialectal work focuses on the morpho-syntactical level (Chamoreau 2005). Neither Friedrich nor Chavez mention age nor gender of their speakers and did not use any computer programme for analyzing their data so as to support their claims. We address the same questions as theirs: what are some dialectal differences? And add a new one: Is there any generational difference among speakers of the same gender?

We applied a questionnaire to subjects whose first language is Tarascan and use it in everyday communication with family and friends, but they also speak Spanish for commercial purposes and with foreigners. The subjects were as follows: i) two men from Janitzio and one man from Santa fe (lake dialects); one man from Capacuaro, (mountain dialect). All men are in between 50 and 60 years old. We also applied it to ii) one woman from Janitzio and one woman from Capacuaro, 45 and 47 years old respectively; iii) one young man, 25 and a girl, 23 years old both from Janitzio.

ExLing 2010: Proceedings of 3rd Tutorial and Research Workshop on Experimental Linguistics, 25-27 August, Athens, Greece 
The questionnaire is made up with 80 isolated words based on a grammar and a dictionary (Foster 1969, Velásques 1987). We asked speakers repeat each word twice and recorded them with a Sony digital recorder ICD-UX71. These words had i) a non-aspirated stop initially, i.e. tareri 'snake', tumina 'money' etc.; ii) an aspirated stop initially i.e. phiran 'take off', thiren 'eat'; iii) the five vowels /i, e, a, o, u/ word initially and iv) each vowel following both types of stops.

\section{Methodology}

We analyzed all data in PRAAT programme and i) measure the length of the stop's aspirated feature; ii) find the middle part of the vowel $(/ \mathrm{i}, \mathrm{a}, \mathrm{u} /)$ that followed the aspirated stop so as get its F1 and F2; iii) got some mean values by gender, dialect, speaker and age.

\section{Results}

Men from the lake dialect do an aspiration longer than that of men from the mountain dialect (Table 1). The opposite pattern applies for the mountain woman who does a slightly longer aspiration than the woman from the lake (Table 2).

Table 1. Men: different aspiration length in dialects.

\begin{tabular}{|l|l|l|l|l|}
\hline \hline Stop & Lake dialect & $\mathrm{N}$ & mountain dialect & $\mathrm{N}$ \\
\hline $\mathrm{ph}$ & 0.134 & 11 & 0.065 & 4 \\
\hline th & 0.108 & 7 & 0.068 & 4 \\
\hline $\mathrm{kh}$ & 0.155 & 15 & 0.084 & 8 \\
\hline \hline
\end{tabular}

Table 2. Women: different aspiration length in dialects.

\begin{tabular}{|l|l|l|l|l|}
\hline \hline Stop & Lake dialect & $\mathrm{N}$ & mountain dialect & $\mathrm{N}$ \\
\hline $\mathrm{ph}$ & 0.072 & 4 & 0.090 & 3 \\
\hline th & 0.096 & 3 & 0.101 & 5 \\
\hline $\mathrm{kh}$ & 0.106 & 7 & 0.105 & 4 \\
\hline \hline
\end{tabular}

There are also dialectal differences based on men's F1 and F2 (table 3). The man's F2 from the mountain dialect is lower than men's F2 from lake, except for vowel /i/ following the three aspirated stops /ph, th, kh/ and one instance of the vowel $/ \mathrm{u} /$ following an aspirated velar $/ \mathrm{kh} /$. There is a much transparent dialectal difference between women. F2 values from the mountain dialect are lower than F2 from the lake dialect, except for vowel $/ \mathrm{u} /$ following a velar $/ \mathrm{kh} /$ (table 4$)$. 
Table 3. >en: difference in F1 and F2 values in dialects.

\begin{tabular}{|c|c|c|c|c|c|c|c|}
\hline Stop & Vowel & \multicolumn{2}{|c|}{ Lake dialect } & $\mathrm{N}$ & \multicolumn{2}{|c|}{ Mountain dialect } & $\mathrm{N}$ \\
\hline & $/ \mathrm{a} /$ & F1 & $\mathrm{F} 2$ & & F1 & $\mathrm{F} 2$ & \\
\hline $\mathrm{ph}$ & & 917 & 1457 & 3 & 745 & 1298 & 2 \\
\hline th & & 697 & 1611 & 2 & 752 & 1599 & 1 \\
\hline $\mathrm{kh}$ & & 786 & 1844 & 4 & 760 & 1466 & 1 \\
\hline & /i/ & & & & & & \\
\hline ph & & 375 & 2084 & 2 & 376 & 2175 & 1 \\
\hline th & & 359 & 2010 & 4 & 372 & 2144 & 2 \\
\hline $\mathrm{kh}$ & & 426 & 1956 & 3 & 370 & 2142 & 3 \\
\hline & $/ \mathrm{u} /$ & & & & & & \\
\hline ph & & 597 & 1746 & 6 & 443 & 1182 & 1 \\
\hline th & & 838 & 1869 & 1 & 711 & 1161 & 2 \\
\hline $\mathrm{kh}$ & & 560 & 1748 & 8 & 618 & 1857 & 3 \\
\hline
\end{tabular}

Table 4. Women: difference in F1 and F2 values in dialects.

\begin{tabular}{|c|c|c|c|c|c|c|c|}
\hline Stop & vowel & \multicolumn{2}{|c|}{ Lake dialect } & $\mathrm{N}$ & \multicolumn{2}{|c|}{ Mountain dialect } & $\mathrm{N}$ \\
\hline & /a/ & $\mathrm{F} 1$ & $\mathrm{~F} 2$ & & $\mathrm{~F} 1$ & $\mathrm{~F} 2$ & \\
\hline $\mathrm{ph}$ & & 897 & 1762 & 2 & 953 & 1586 & 1 \\
\hline th & & 935 & 1891 & 2 & 835 & 1523 & 1 \\
\hline $\mathrm{kh}$ & & 807 & 1847 & 2 & 801 & 1779 & 1 \\
\hline & /i/ & & & & & & \\
\hline ph & & 376 & 2611 & 1 & 390 & 2152 & 1 \\
\hline th & & 442 & 2675 & 2 & 419 & 2338 & 2 \\
\hline $\mathrm{kh}$ & & 485 & 2531 & 2 & 494 & 2196 & 2 \\
\hline & $/ \mathrm{u} /$ & & & & & & \\
\hline $\mathrm{ph}$ & & 496 & 949 & 1 & 600 & 869 & 1 \\
\hline th & & 813 & 1423 & 1 & 714 & 1187 & 3 \\
\hline $\mathrm{kh}$ & & 383 & 936 & 2 & 470 & 1136 & 1 \\
\hline
\end{tabular}

Regarding generational differences, a young man does a shorter aspiration than older men (table 5), while there is not a clear pattern for women of different age (table 6).

Table 5. Men generational differences in aspiration length.

\begin{tabular}{|l|l|l|l|l|}
\hline \hline Stop & $\begin{array}{l}\text { young man 25 } \\
\text { y.ld }\end{array}$ & $\mathrm{N}$ & men 60-70 y.ld & $\mathrm{N}$ \\
\hline $\mathrm{ph}$ & 0.082 & 5 & 0.102 & 16 \\
\hline th & 0.091 & 6 & 0.099 & 12 \\
\hline $\mathrm{kh}$ & 0.087 & 6 & 0.135 & 19 \\
\hline \hline
\end{tabular}


Table 6. Women generational differences in aspiration length.

\begin{tabular}{|l|l|l|l|l|}
\hline \hline Stop & girl 23 y.ld & $\mathrm{N}$ & women 45-47 y.ld & $\mathrm{N}$ \\
\hline $\mathrm{ph}$ & 0.079 & 8 & 0.068 & 6 \\
\hline th & 0.069 & 1 & 0.098 & 8 \\
\hline kh & 0.102 & 6 & 0.089 & 10 \\
\hline \hline
\end{tabular}

So far we can partially answer our questions: what are some dialectal differences? There are some dialectal differences given by the measurement of the aspirated feature in stops. The man from the mountain dialect does a shorter aspiration, while the women from the same dialect does a slightly longer aspiration than their respective gender speakers from the lake dialect. Another difference is given by the F2 value. Both, the woman and the man from the mountain tend to have an F2 lower in all vowels following aspirated stops, except for the man's F2 for vowel /i/ which is higher than that of the lake dialect.

Is there any generational difference? The young man's $\mathrm{F} 1$ and $\mathrm{F} 2$ values tend to be higher than the old men's, while it is the opposite pattern for the girl whose F1 and F2 values are lower than older women.

The length of the aspirated feature has some consequences for the hearer since the longer the aspiration the more perceptible it is. Probably Friedrich (1971) had not perceived this difference and made him state that a lake dialect was losing its aspiration contrast with stops. The vowel's F1 and F2 also show generational differences that have not been considered before in this language. Although all these results are based on few speakers, future data is needed to confirm or debunk the above claims.

\section{References}

Boersma, P. 2001. Praat, a system for doing phonetics by computer. Glot International 5:9/10, 341-345.

Chamoreau, C. 2005. Dialectología y dinámica: reflexiones a partir del p'urépecha. Trace, 47, 61-81.

Chávez, R.D.A. 2004. Aproximación a la dialectología de la lengua purépecha. MA thesis, México, CIESAS.

Foster, M.L. 1969. The Tarascan Language. Berkley-Los angeles, University of California press.

Friedrich, P. 1971. Dialectal variation in tarascan phonology. IJAL, 3, 32, 164-187.

Velásques, G.P. 1987. Diccionario de la lengua phorépecha. México, Fondo de cultura económica. 